\title{
Effects of Extrusion Conditions on Physicochemical Properties of Finger Millet (Gramineae Setaria)
}

\author{
Peng Liu ${ }^{1,2}$, Jianjun Cheng ${ }^{1}$, Ming $\mathrm{Li}^{1}$, Jing $\mathrm{Li}^{1}$, Hongwei Zhu ${ }^{1}$, Shirang Wang ${ }^{1} \&$ Guoping $\mathrm{Yu}^{1}$ \\ ${ }^{1}$ College of Food Science, Northeast Agricultural University, Harbin, China \\ ${ }^{2}$ College of Food Science and Engineering, Tonghua Normal University, Tonghua, China \\ Correspondence: Shirang Wang, College of Food Science, Northeast Agricultural University, No. 600 Changjiang \\ Road, Harbin, China. E-mail: wangshirang2017@126.com \\ Guoping Yu, professor, College of Food Science, Northeast Agricultural University, No. 600 Changiiang Road, \\ Harbin, China. Tel: 86-0451-5519-0128. E-mail: yuguopingneau@hotmail.com
}

Received: May 23, 2020

doi:10.5539/jas.v12n9p149
Online Published: August 15, 2020

URL: https://doi.org/10.5539/jas.v12n9p149

The research is financed by the National Key Research and Development Program of China (2017YFD0401200).

\begin{abstract}
In this study, the effects of different extrusion parameters (extrusion temperature: 100,130 , and $160{ }^{\circ} \mathrm{C}$; moisture content: $22 \%, 26 \%$, and $30 \%$; screw speed: $180 \mathrm{rpm}, 270 \mathrm{rpm}$, and $360 \mathrm{rpm}$ ) on physicochemical properties of finger millet were reviewed. High extrusion temperature produced extrudates with high radial expansion index (REI) and starch digestibility and low bulk density (BD). High moisture content and low screw speed increased BD and total starch content (TSC) while decreasing REI and water solubility index (WSI). WSI and starch digestibility first increased and then decreased with increase in extrusion temperature and moisture content, which reached a maximum at $130{ }^{\circ} \mathrm{C}$ nd $26 \%$, respectively. However, water absorption index (WAI) was affected by the interactions among various conditions. The extrudates were darker and yellower than native millet. Based on these extrusion conditions, various millet and millet-based products can be produced.
\end{abstract}

Keywords: extrusion processing, millet processing, physical properties, starch digestibility, full factorial experiment design

\section{Introduction}

Millet, a small-seeded crop of considerable importance in many parts of the world, especially in Asia and Africa, plays a major role in food supply security (Liang et al., 2018). Reports show that millet is richer in proteins, lipids, and B vitamins than other cereal grains, such as wheat and rice (Parameswaran \& Sadasivam, 1994; Wu et al., 2014). It also contains phytochemicals, such as phenolic acids, flavonoids, tannins, and phytate (Pradeep \& Guha, 2011). Furthermore, millet and millet-based products are known to have lower starch and protein digestibility rates compared to other cereals (Annor et al., 2017), and are beneficial for specific categories of individuals (e.g. diabetics and obese people).

Extrusion processing technology was usually used in the food industry, especially grain processing, due to its advantages of high efficiency, low cost and convenience (Shivendra et al., 2010). Extrusion is a high temperature short time process, which combines several steps, including heat and mass transfer, mixing, shearing, particle size reduction, melting, texturizing, caramelizing, and shaping (Nikmaram et al., 2017). Extrusion of food can be utilized to manufacture various types of food products combined with the merits of a completely automated technology that allow efficient use of energy during cooking and better process control (Alonso et al., 2000; Zhao et al., 2015). In addition, extrusion parameters such as the screw speed, extrusion temperature, and moisture content can affect the properties of extrudates. Extrusion with high moisture content $(50 \mathrm{~g} / 100 \mathrm{~g}$ or 60 $\mathrm{g} / 100 \mathrm{~g}$ ) and two screw speeds (200 rpm or $300 \mathrm{rpm}$ ) can keep the high level of $\beta$-glucan in oats from being destroyed, so that its molecular weight, total solids content and thermal characteristics can be maintained (Sayanjali et al., 2017). Corn and soybean blends were extruded with a higher specific mechanical energy (SME) showed a higher water solubility index and the water absorption rate showed an upward trend at the initial stage, but showed a downward trend with the increase of SME (Guo et al., 2018). 
Previous studies have reported that extruded millet compounded with other cereals improve the quality and functionality of the products. Extrusion cooking of millet, cowpea, and sorghum was used for the production of weaning food items. Extrusion of decorticated millet at 13-15\% moisture content produced expanded extrudates with low bulk density, high water solubility and molecular dispersion of starch. Extrusion moisture of decorticated millet at $15 \%$ moisture produced the highest radial expansion, water solubility, and molecular dispersion of starch (Almeidadominguez et al., 1993). Extruded millet flour $(20 \mathrm{~g} / 100 \mathrm{~g})$ in composite bread can reverse the increased firmness and reduced extensibility contributed by native flour substitutes (Patil et al., 2016). Kharat et al. (2019) reported the extrusion processing characteristics of whole grain flours of major millets (finger, foxtail and pearl), and showed that whole grain foxtail millet flour was the best among the three millets tested in their study for expanding the millet-based product repertoire. Different fiber content in these kinds of millet is the main reason for this result. In addition, the nutritional properties of major millets are not affected by extrusion conditions (Swapnil et al., 2018).

However, information regarding the effect of extrusion conditions on physicochemical properties and in vitro digestibility of millet is limited. Hence, we investigated the effect of different extrusion conditions (extrusion temperature, screw speed, and moisture content) on physicochemical properties (radial expansion index (REI), bulk density (BD), water solubility index (WSI), water absorption index (WAI), and total starch content (TS)) and in vitro starch digestibility of finger millet. In order to provide a certain theoretical basis for the development of millet and millet-based food by extrusion.

\section{Materials and Method}

\subsection{Millet}

The millet (Gramineae Setaria variety Shishe), used in this study was acquired from Qingyang Academy of Agricultural Sciences (Qingyang, Gansu, China).

\subsection{Millet flour Composition}

The millet was ground in a mixer (GEX GPD-1000C, Taizhou, China) through an 80 mesh sieve. The composition of millet flours was determined following the guidelines of the Association of Official Analytical Chemists (AOAC). Moisture, ash, lipid content, and protein content $(\% \mathrm{~N} \times 6.25$; protein coefficient $)$ were determined according to the AOAC 2000 guidelines (method numbers 925.10, 923.03, 920.85, and 984.13, respectively). Ash, lipid content, and protein content were reported on a percent dry weight basis (d.b.). Carbohydrate content was computed by difference. Total starch concentration was determined using an acid hydrolysis kit (BC0705, Solarbio, Beijing, China).

\subsection{Extrusion Condition}

Millet flour was extruded in a twin screw extruder (DS56-III type, Ji'nan Sai Shun puffing Machinery Co., Ltd Jinan,China) at different barrel temperatures $\left(100,130\right.$, and $\left.160{ }^{\circ} \mathrm{C}\right)$, feed moisture $(22 \%, 26 \%$, and $30 \%)$, and screw speeds $(180,270$, and $360 \mathrm{rpm})$ as shown in Table 1 . The setting of extrusion parameters refers to the studies of Brahma et al. (2016) and Kharat et al. (2019) with slight modification. The extrudate was ground and stored at $-4{ }^{\circ} \mathrm{C}$. 
Table 1. Extrusion experiment design

\begin{tabular}{|c|c|c|c|c|c|c|c|}
\hline No. & $\begin{array}{l}\text { Barrel temperature } \\
\left({ }^{\circ} \mathrm{C}\right)\end{array}$ & $\begin{array}{l}\text { Feed moisture } \\
(\%)\end{array}$ & $\begin{array}{l}\text { Screw speed } \\
(\mathrm{rpm})\end{array}$ & No. & $\begin{array}{l}\text { Barrel temperature } \\
\left({ }^{\circ} \mathrm{C}\right)\end{array}$ & $\begin{array}{l}\text { Feed moisture } \\
(\%)\end{array}$ & $\begin{array}{l}\text { Screw speed } \\
(\mathrm{rpm})\end{array}$ \\
\hline 1 & 100 & 30 & 180 & 15 & 130 & 26 & 360 \\
\hline 2 & 100 & 30 & 270 & 16 & 130 & 22 & 180 \\
\hline 3 & 100 & 30 & 360 & 17 & 130 & 22 & 270 \\
\hline 4 & 100 & 26 & 180 & 18 & 130 & 22 & 360 \\
\hline 5 & 100 & 26 & 270 & 19 & 160 & 30 & 180 \\
\hline 6 & 100 & 26 & 360 & 20 & 160 & 30 & 270 \\
\hline 7 & 100 & 22 & 180 & 21 & 160 & 30 & 360 \\
\hline 8 & 100 & 22 & 270 & 22 & 160 & 26 & 180 \\
\hline 9 & 100 & 22 & 360 & 23 & 160 & 26 & 270 \\
\hline 10 & 130 & 30 & 180 & 24 & 160 & 26 & 360 \\
\hline 11 & 130 & 30 & 270 & 25 & 160 & 22 & 180 \\
\hline 12 & 130 & 30 & 360 & 26 & 160 & 22 & 270 \\
\hline 13 & 130 & 26 & 180 & 27 & 160 & 22 & 360 \\
\hline 14 & 130 & 26 & 270 & & & & \\
\hline
\end{tabular}

\subsection{Physical Properties of Extruded Millet Flour}

\subsubsection{Radial Expansion Index (REI)}

REI was computed according to the diameter of the extrudates divided by the die diameter. Then the diameter of the extrudates was determined using a Vernier calliper (Shanghai Measuring \& Cutting Tool Works Co. Ltd., Shanghai, China) with an accuracy of $0.1 \mathrm{~mm}$. Each sample was measured ten times.

\subsubsection{Bulk Density (BD)}

BD was determined according to the methods described by Natabirwa et al. (2017). A known amount of sample was packed in a $1,000 \mathrm{~mL}$ graduated cylinder with an accuracy of $10 \mathrm{~mL}$, after which the cylinder was tapped gently 20 times on the bench top. When the content volume did not reduce further, the volumetric measurement was accurately recorded, and the result was expressed as follows:

$$
\mathrm{BD}\left(\mathrm{g} / \mathrm{cm}^{3}\right)=\frac{\text { Sample quality }(\mathrm{g})}{\text { Sample volume }\left(\mathrm{cm}^{3}\right)}
$$

\subsubsection{Water Solubility Index (WSI) and Water Absorption Index (WAI)}

The WSI and WAI of raw and extruded millet flour were determined using the method of Jongsutjarittam and Charoenrein with slight modifications (Jongsutjarittam \& Charoenrein, 2014). The samples (about $2 \mathrm{~g}$ on dry weight basis) were dispersed in $10 \mathrm{~mL}$ water for $30 \mathrm{~min}$ at $30^{\circ} \mathrm{C}$ with vortex mixing once in every five minutes. Next, they were detached using a centrifuge (5810R, Eppendorf, Hamburg, Germany) at $3000 \times \mathrm{g}$ for $15 \mathrm{~min}$. The supernatant was poured into an aluminum can and dried in the hot air oven at $105^{\circ} \mathrm{C}$ for $6 \mathrm{~h}$. WSI and WAI were calculated as follows:

\subsubsection{Appearance Attributes}

$$
\begin{aligned}
& \text { WSI }(\%)=\frac{\text { Sample mass supernatant }(\mathrm{g})}{\text { Sample mass }(\mathrm{g})} \times 100 \\
& \text { WAI }(\mathrm{g} / \mathrm{g})=\frac{\text { Sample mass with absorbed water }(\mathrm{g})}{\text { Sample mass }(\mathrm{g})}
\end{aligned}
$$

Color measurements were performed on raw and extruded millet flour using a ZE 6000 colorimeter (Nippon Denshoku, Kogyo Co., Tokyo, Japan). The color of the extrudates was expressed as the average of three L*, a*, and $\mathrm{b}^{*}$ readings. Each sample was measured thrice.

\subsubsection{In vitro Starch Digestibility of Extruded Millet Flour}

In vitro starch digestibility of extrudates was determined using the method of Minekus et al. (2014). For simulating intestinal enzymatic hydrolysis, aliquots $(5 \mathrm{~mL})$ of the digested solution were placed in test tubes for 0,20 , and $120 \mathrm{~min}$, and immediately placed in a boiling water bath for $5 \mathrm{~min}$ to inactivate $\alpha$-amylase. Subsequently, 3,5-dini-trosalicylic acid reagent was added to determine reducing sugar concentration, and the absorbance of the solution was measured at $550 \mathrm{~nm}$ using maltose as a standard. Each sample was measured thrice. In vitro starch digestibility was calculated according to the method of Englyst et al. (1992). The 
digestibility of starch was characterized using rapidly digestible starch (RDS), slowly digestible starch (SDS), and resistant starch (RS), and was calculated as follows:

$$
\begin{gathered}
\operatorname{RDS}(\%)=(\mathrm{G} 20-\mathrm{FG}) \times 0.9 / \mathrm{TS} \times 100 \\
\mathrm{SDS}(\%)=(\mathrm{G} 120-\mathrm{G} 20) \times 0.9 / \mathrm{TS} \times 100 \\
\mathrm{RS}(\%)=1-(\mathrm{RDS}+\mathrm{SDS})
\end{gathered}
$$

\subsection{Data Analysis}

A three-factor ANOVA was applied with extrusion temperature, moisture content, and screw speed as the main effects, while including all the two-way and three-way interactions in the ANOVA model for comparisons among extrudates. Contributions of each factor to the whole ANOVA model were calculated by dividing each factor's sum of squares by the total sum of squares and multiplying by 100 . This can effectively and accurately show the contribution of each factor to the response. All data were analyzed using the SPSS software (SPSS version 20.0, IBM Statistics, New York, USA). Responses are shown as mean \pm standard deviation.

\section{Results and Discussion}

\subsection{Millet flour Composition}

Millet flour composition is shown in Table 2.

Table 2. Millet flour composition

\begin{tabular}{llllll}
\hline Component & Value & Component & Value & Color & Value \\
\hline Moisture $(\%, \mathrm{wb})$ & $10.37 \pm 0.03$ & Ash $(\%, \mathrm{db})$ & $1.87 \pm 0.05$ & $\mathrm{~L}^{*}$ & $87.03 \pm 0.3$ \\
Protein $(\%, \mathrm{db})$ & $11.96 \pm 0.33$ & Carbohydrate $(\%, \mathrm{db})$ & 75.25 & $\mathrm{a}^{*}$ & $1.28 \pm 0.04$ \\
Lipid $(\%, \mathrm{db})$ & $10.92 \pm 0.12$ & Total starch $(\% \mathrm{db})$ & $66.10 \pm 0.02$ & $\mathrm{~b}^{*}$ & $22.36 \pm 0.29$ \\
\hline
\end{tabular}

\subsection{Effect of Extrusion Conditions on Physical Properties of Millet Extrudates}

The effects of extrusion conditions on the physical properties of millet extrudates are listed in Table 3 and the statistical results are listed in Table 4. 
Table 3. Effect of processing variables on physical properties of millet extrudates

\begin{tabular}{|c|c|c|c|c|c|c|c|}
\hline \multirow{2}{*}{ No. } & \multirow{2}{*}{ REI } & \multirow{2}{*}{$\mathrm{BD}\left(\mathrm{g} / \mathrm{cm}^{3}\right)$} & \multirow{2}{*}{ WAI (g/g) } & \multirow{2}{*}{ WSI (\%) } & \multicolumn{3}{|c|}{ Color } \\
\hline & & & & & $\mathrm{L}^{*}$ & $\mathrm{a}^{*}$ & $b^{*}$ \\
\hline 1 & $2.41 \pm 0.33$ & $0.88 \pm 0.20$ & $2.32 \pm 0.11$ & $3.93 \pm 0.07$ & $83.88 \pm 0.02$ & $1.28 \pm 0.02$ & $32.51 \pm 0.02$ \\
\hline 2 & $2.39 \pm 0.24$ & $0.87 \pm 0.09$ & $2.11 \pm 0.09$ & $4.27 \pm 0.12$ & $83.8 \pm 0.09$ & $1.56 \pm 0.09$ & $35.08 \pm 0.12$ \\
\hline 3 & $2.81 \pm 0.39$ & $0.70 \pm 0.08$ & $3.09 \pm 0.21$ & $4.35 \pm 0.02$ & $83.89 \pm 0.01$ & $1.5 \pm 0.04$ & $34.52 \pm 0.01$ \\
\hline 4 & $2.42 \pm 0.17$ & $0.84 \pm 0.14$ & $2.93 \pm 1.14$ & $4.32 \pm 0.05$ & $83.95 \pm 0.1$ & $1.4 \pm 0.03$ & $34.11 \pm 0.11$ \\
\hline 5 & $2.69 \pm 0.40$ & $0.73 \pm 0.10$ & $7.59 \pm 0.01$ & $5.07 \pm 0.05$ & $83.37 \pm 0.13$ & $1.5 \pm 0.07$ & $34.88 \pm 0.17$ \\
\hline 6 & $2.74 \pm 0.37$ & $0.77 \pm 0.14$ & $10.67 \pm 0.55$ & $5.05 \pm 0.05$ & $83.09 \pm 0.07$ & $1.33 \pm 0.1$ & $33.79 \pm 0.32$ \\
\hline 7 & $2.19 \pm 0.23$ & $0.74 \pm 0.05$ & $5.01 \pm 0.20$ & $4.2 \pm 0.02$ & $83.97 \pm 0.1$ & $1.23 \pm 0.02$ & $33.26 \pm 0.29$ \\
\hline 8 & $3.55 \pm 0.36$ & $0.67 \pm 0.06$ & $12.84 \pm 0.07$ & $5.09 \pm 0.01$ & $83.48 \pm 0.11$ & $1.32 \pm 0.03$ & $33.61 \pm 0.37$ \\
\hline 9 & $2.69 \pm 0.18$ & $0.55 \pm 0.06$ & $15.04 \pm 0.51$ & $4.77 \pm 0.03$ & $83.37 \pm 0.07$ & $1.25 \pm 0.02$ & $32.37 \pm 1$ \\
\hline 10 & $2.52 \pm 0.26$ & $0.74 \pm 0.17$ & $4.69 \pm 0.04$ & $5.36 \pm 0.05$ & $83.64 \pm 0.05$ & $1.33 \pm 0.05$ & $31.88 \pm 0.24$ \\
\hline 11 & $2.75 \pm 0.16$ & $0.60 \pm 0.09$ & $10.45 \pm 0.70$ & $5.57 \pm 0.07$ & $83.36 \pm 0.07$ & $1.36 \pm 0.02$ & $33.58 \pm 0.44$ \\
\hline 12 & $3.26 \pm 0.37$ & $0.52 \pm 0.03$ & $13.82 \pm 0.93$ & $4.99 \pm 0.04$ & $83.18 \pm 0.25$ & $1.37 \pm 0.06$ & $32.37 \pm 0.8$ \\
\hline 13 & $2.38 \pm 0.68$ & $0.81 \pm 0.12$ & $5.15 \pm 0.10$ & $5.16 \pm 0.11$ & $83.34 \pm 0.12$ & $1.42 \pm 0.03$ & $32.29 \pm 0.17$ \\
\hline 14 & $3.59 \pm 0.32$ & $0.59 \pm 0.13$ & $13.76 \pm 0.76$ & $4.91 \pm 0.05$ & $82.52 \pm 0.16$ & $1.15 \pm 0.03$ & $29.39 \pm 0.3$ \\
\hline 15 & $4.15 \pm 0.51$ & $0.36 \pm 0.06$ & $14.71 \pm 0.71$ & $5.21 \pm 0.05$ & $84.02 \pm 0.07$ & $1.17 \pm 0.03$ & $30.34 \pm 0.49$ \\
\hline 16 & $3.01 \pm 0.12$ & $0.45 \pm 0.05$ & $11.74 \pm 0.10$ & $5.12 \pm 0.64$ & $83.24 \pm 0.02$ & $1.17 \pm 0.01$ & $31.1 \pm 0.28$ \\
\hline 17 & $4.32 \pm 0.47$ & $0.26 \pm 0.04$ & $15.17 \pm 0.42$ & $5.24 \pm 0.02$ & $83.8 \pm 0.14$ & $1.06 \pm 0.06$ & $29.4 \pm 0.22$ \\
\hline 18 & $5.37 \pm 0.75$ & $0.25 \pm 0.05$ & $21.1 \pm 1.41$ & $5.12 \pm 0.03$ & $83.91 \pm 0.13$ & $1.04 \pm 0.05$ & $27.95 \pm 0.3$ \\
\hline 19 & $3.63 \pm 0.30$ & $0.69 \pm 0.08$ & $8.95 \pm 0.07$ & $4.46 \pm 0.01$ & $83.14 \pm 0.05$ & $1.25 \pm 0.01$ & $33.45 \pm 0.07$ \\
\hline 20 & $3.04 \pm 0.95$ & $0.61 \pm 0.11$ & $6.21 \pm 4.11$ & $4.64 \pm 0.01$ & $83.37 \pm 0.13$ & $1.26 \pm 0.05$ & $33.49 \pm 0.19$ \\
\hline 21 & $3.15 \pm 0.51$ & $0.65 \pm 0.08$ & $7.88 \pm 0.14$ & $4.2 \pm 0.02$ & $82.73 \pm 0.09$ & $1.47 \pm 0.03$ & $33.84 \pm 0.2$ \\
\hline 22 & $3.07 \pm 0.55$ & $0.55 \pm 0.05$ & $10.58 \pm 0.02$ & $5.14 \pm 0.01$ & $83.63 \pm 0.08$ & $1.17 \pm 0.03$ & $33.2 \pm 0.25$ \\
\hline 23 & $2.80 \pm 0.22$ & $0.65 \pm 0.09$ & $11.02 \pm 0.29$ & $5.25 \pm 0.08$ & $83.39 \pm 0.05$ & $1.28 \pm 0.04$ & $33.23 \pm 0.31$ \\
\hline 24 & $3.69 \pm 0.26$ & $0.44 \pm 0.07$ & $12.99 \pm 0.59$ & $5.24 \pm 0.06$ & $83.57 \pm 0.15$ & $1.18 \pm 0.05$ & $31.56 \pm 0.19$ \\
\hline 25 & $3.02 \pm 0.31$ & $0.54 \pm 0.09$ & $11.49 \pm 0.12$ & $5.54 \pm 0.03$ & $84.04 \pm 0.07$ & $0.94 \pm 0.02$ & $30.61 \pm 0.24$ \\
\hline 26 & $4.54 \pm 0.44$ & $0.33 \pm 0.05$ & $15.42 \pm 0.48$ & $5.27 \pm 0.2$ & $84.23 \pm 0.07$ & $1.01 \pm 0.03$ & $29.5 \pm 0.54$ \\
\hline 27 & $5.67 \pm 0.49$ & $0.17 \pm 0.03$ & $18.79 \pm 0.52$ & $5.44 \pm 0.01$ & $84.16 \pm 0.05$ & $0.94 \pm 0.03$ & $28.39 \pm 0.32$ \\
\hline
\end{tabular}

Table 4. Factor contributions (\%) to ANOVA models for physical properties of millet extrudates

\begin{tabular}{llllllll}
\hline \multirow{2}{*}{ Factor } & REI & \multirow{2}{*}{ BD } & WSI & WAI & \multicolumn{2}{c}{ Color } \\
\cline { 6 - 7 } & & & & $\mathrm{L}^{*}$ & $\mathrm{a}^{*}$ & $\mathrm{~b}^{*}$ \\
$\mathrm{~T}$ & $34.44^{* * *}$ & $23.42^{* * *}$ & $29.77^{* * *}$ & $14.90^{* * *}$ & $3.45^{* * *}$ & $28.84^{* * *}$ & $37.09^{* * *}$ \\
$\mathrm{SS}$ & $31.76^{* * *}$ & $20.61^{* * *}$ & $36.99^{* * *}$ & $14.03^{* * *}$ & $16.45^{* * *}$ & $41.49^{* * *}$ & $31.31^{* * *}$ \\
$\mathrm{~T}$ & $17.73^{* * *}$ & $20.73^{* * *}$ & $16.78^{* * *}$ & $3.60^{*}$ & $1.99^{* * *}$ & 0.56 & $2.55^{* * *}$ \\
$\mathrm{~T}$ & $2.72^{* * *} \mathrm{SS}$ & $6.65^{* * *}$ & 0.91 & $10.74^{* * *}$ & $27.91^{* * *}$ & $3.32^{* * *}$ & $11.30^{* * *}$ \\
$\mathrm{M}$ & $1.96^{*} \mathrm{SS}$ & $6.86^{* * *}$ & $2.12^{* * *}$ & 4.76 & $14.74^{* * *}$ & $9.15^{* * *}$ & $4.74^{* * *}$ \\
$\mathrm{~T}^{*} \mathrm{M} \mathrm{SS}$ & 1.34 & $11.76^{* * *}$ & $5.12^{* * *}$ & $20.39^{* * *}$ & $10.39^{* * *}$ & $7.41^{* * *}$ & $8.32^{* * *}$ \\
Error & $7.31^{* * *}$ & $7.54^{* * *}$ & $6.50^{* * *}$ & $24.63^{* * *}$ & $21.01^{* * *}$ & $5.55^{* * *}$ & $3.77^{* * *}$ \\
\hline
\end{tabular}

Note. ${ }^{*} \mathrm{p}<0.05 ; * * \mathrm{p}<0.01 ; * * * \mathrm{p}<0.001$.

\subsubsection{Radial Expansion Index (REI) and Bulk Density (BD)}

The REI of the extrudates ranged between 2.19 and 5.67 (Table 3). REI decreased with increase in moisture content, whereas it increased with screw speed and extrusion temperature. The increase in REI with screw speed was possibly because of increased water vapor pressure at the die nozzle, which resulted in bubble growth (Hagenimana et al., 2006). Decrease in REI at high moisture content may be attributed to reduced elasticity of dough because of plasticization of the melt in the extruder (Tucker et al., 2006). These results suggested that high extrusion temperature, low moisture content, and high screw speed are critical for attaining high REI of extrudates.

The BD of the extrudates ranged between 0.17 and $0.88 \mathrm{~g} / \mathrm{cm}^{3}$ (Table 3), which increased with moisture content and decreased with screw speed and extrusion temperature. It is noteworthy that BD increased slightly when the 
extrusion temperature was high $\left(160^{\circ} \mathrm{C}\right)$. High extrusion temperature may lead to high die pressure, rapid vaporization of water, and enhanced rupture of bubbles, which may slightly decrease BD. Higher screw speed results in lower bulk density of the extrudates, which was similar to the results of previous reports. Suksomboon et al. (2011) found the BD of snacks (purple rice and soybean flour blend) increased directly with moisture content at all exteusion temperatures and screw speeds $(\mathrm{P}<0.05)$, however, high extruion temperature an high screw speed led to decrease in $\mathrm{BD}$ of extrudates $(\mathrm{P}<0.05)$. High $\mathrm{BD}$ at high moisture content may be due to the plasticizing and lubricating effect of water, which reduces the machine-shear effects and starch disintegration in the extruder (Maskan and Altan, 2011). Yu and Ramaswamy (2012) found that the moisture content had the most significant effect on the BD of extrudates, when analyzing the mixture of corn flour and soybean protein isolate with response surface methodology, in which the moisture content surface plot concaved at mid-moisture content somewhat similarly with both temperature and screw speed indicating a lower BD.

\subsubsection{Water solubility index (WSI) and water absorption index (WAI)}

WSI and WAI of the extrudates varied from $2.11 \%$ to $18.79 \%$ and 3.93 to $5.57 \mathrm{~g} / \mathrm{g}$, respectively (Table 3). The extrudates had an obviously higher WSI and WAI than that of unextrudates $(2.22 \%$ and $3.14 \mathrm{~g} / \mathrm{g})$, in addition to extrusion at low temperature and high moisture content.

WSI represents the amount of water-soluble components that disperse in aqueous phase during cooking. Higher WSI indicates higher adhesiveness and stickiness in food products (Kraithong et al., 2017). Higher screw speed and lower moisture content can result in higher WSI, and it exhibited a maximum within the moisture range tested. Extrudates with higher screw speed showed higher WSI value, which was possibly due to the disruption of the macromolecules (mainly starch), resulting in high solubility of small molecules (Guo et al., 2018). Higher moisture content during extrusion processing resulted in lower starch gelatinization; the extrudate probably acted as a plasticizer because of less starch degradation and shear force, which decreased WSI (Diasmartins et al., 2018).

WAI indicates the ability of native and extruded millet flour to associate with water molecules (Shafi et al., 2016). All the variables of extrusion processing can significantly modify the WAI of extrudates. However, the effect of individual extrusion parameters on WAI is not obvious; in contrast, ANOVA shows that WAI of the extruded product is affected by the interactions of multiple extrusion parameters (Table 4). Examining the raw rice flour, it was found that the extrusion can increase WAI of the samples (from 2.42 to above 7.0), while the variables in the extrusion process were not able to significantly modify the water absorption values (Teba et al., 2017). Yadav et al. (2014) also found that the WAI of the extrudate had no significant relationship with the extrusion conditions and was related to the content of whey protein when studying millet-whey protein snacks.

\subsubsection{Appearance Attributes}

The color properties of millet flour before and after extrusion were surveyed. The lightness $\left(\mathrm{L}^{*}\right)$, redness $\left(\mathrm{a}^{*}\right)$, and yellowness $\left(\mathrm{b}^{*}\right)$ of the extrudates varied from 82.52 to $84.23,0.94$ to 1.47 , and 27.95 to 34.88 , respectively (Table 3). $\mathrm{L}^{*}$, $\mathrm{a}^{*}$, and $\mathrm{b}^{*}$ of raw millet flour were $87.02,1.27$, and 22.36 (Table 2), respectively. These results indicated that extrusion processing decreased $\mathrm{L}^{*}$ and increased $\mathrm{b}^{*}$ of millet flour. Nevertheless, extrusion processing changed the color slightly to red $\left(\mathrm{a}^{*}\right)$. The main factor responsible for changes in color properties is the Maillard reaction, which is divided into three steps: in the initial phase, in which a reaction between reducing sugar and amines results in colorless products; slightly yellow or colourless products are formed in the middle phase, whereas intense colored products are the outcome of the last phase of the process (Ames, 1998). Zhang et al. (2017) also observed the value of $L^{*}$ of canola meal after extrusion was significantly lower than that of unextruded. At high-temperature conditions, the increase in the moisture content decreased the lightness.

\subsection{Effect of Processing Conditions on Starch Content and Digestion of Millet Extrudates}

The effects of extrusion conditions on starch content and digestion of millet extrudates are listed in Table 5 and the statistical results are listed in Table 6. 
Table 5. Effect of processing variables on content and digestion of millet extrudates

\begin{tabular}{lllll}
\hline No. & TSC $(\%, \mathrm{db})$ & RDS $(\%, \mathrm{TS})$ & SDS $(\%, \mathrm{TS})$ & RS $(\%, \mathrm{TS})$ \\
\hline 1 & $63.37 \pm 2.01$ & $83.37 \pm 1.65$ & $12.85 \pm 1.67$ & $3.79 \pm 0.27$ \\
2 & $64.33 \pm 4.2$ & $82.97 \pm 4.15$ & $14.57 \pm 0.32$ & $2.47 \pm 3.85$ \\
3 & $64.4 \pm 1.1$ & $83.77 \pm 0.21$ & $12.53 \pm 1.85$ & $3.7 \pm 1.65$ \\
4 & $63.2 \pm 3.05$ & $84.73 \pm 2.05$ & $12.57 \pm 2.57$ & $3.8 \pm 0.75$ \\
5 & $63.13 \pm 0.15$ & $84.3 \pm 1.25$ & $11.3 \pm 3.56$ & $4.4 \pm 2.35$ \\
6 & $61.57 \pm 3.06$ & $85.03 \pm 0.51$ & $9.51 \pm 1.61$ & $5.46 \pm 1.12$ \\
7 & $59.3 \pm 2$ & $79.5 \pm 1.2$ & $13.5 \pm 2.75$ & $7 \pm 1.55$ \\
8 & $61.73 \pm 4.9$ & $80.9 \pm 1.71$ & $12.1 \pm 1.3$ & $7.0 \pm 0.79$ \\
9 & $61.67 \pm 2$ & $81.83 \pm 1.15$ & $12.57 \pm 0.5$ & $5.6 \pm 0.66$ \\
10 & $63.13 \pm 3.05$ & $85.37 \pm 7.6$ & $11.8 \pm 1.31$ & $2.83 \pm 6.3$ \\
11 & $63.23 \pm 0.61$ & $84.87 \pm 3.2$ & $14.1 \pm 1.8$ & $1.03 \pm 1.4$ \\
12 & $64.9 \pm 4.29$ & $85.07 \pm 2.25$ & $10.73 \pm 0.95$ & $4.2 \pm 1.66$ \\
13 & $61.77 \pm 0.75$ & $85.53 \pm 2.22$ & $10.72 \pm 2.32$ & $3.75 \pm 4.51$ \\
14 & $64.47 \pm 0.5$ & $85.97 \pm 3.15$ & $10.97 \pm 3.57$ & $3.07 \pm 0.57$ \\
15 & $63.1 \pm 1.1$ & $86.57 \pm 0.7$ & $10.4 \pm 2.21$ & $3.03 \pm 1.5$ \\
16 & $59.6 \pm 1.47$ & $82.43 \pm 2.79$ & $11.57 \pm 2.6$ & $6 \pm 0.62$ \\
17 & $61.8 \pm 2$ & $82.67 \pm 5.3$ & $14.93 \pm 3.87$ & $2.4 \pm 1.73$ \\
18 & $60.93 \pm 0.85$ & $84.5 \pm 2.4$ & $9.03 \pm 0.72$ & $6.47 \pm 3.07$ \\
19 & $61.03 \pm 0.95$ & $85.97 \pm 1.31$ & $10.53 \pm 0.5$ & $3.5 \pm 0.82$ \\
20 & $61 \pm 1.1$ & $85.4 \pm 1.25$ & $13.43 \pm 3.92$ & $1.17 \pm 2.7$ \\
21 & $63.57 \pm 2.8$ & $87.3 \pm 3.5$ & $10.57 \pm 3.4$ & $2.13 \pm 0.12$ \\
22 & $59.97 \pm 3.05$ & $89.13 \pm 0.65$ & $8.75 \pm 2.1$ & $2.12 \pm 1.45$ \\
23 & $62.03 \pm 0.15$ & $88.37 \pm 2.5$ & $8.25 \pm 2.05$ & $3.38 \pm 0.49$ \\
24 & $62 \pm 0$ & $90.07 \pm 3.3$ & $8.07 \pm 4.05$ & $1.87 \pm 0.75$ \\
25 & $59.27 \pm 2.95$ & $84.1 \pm 1.05$ & $11.71 \pm 2.44$ & $4.19 \pm 1.39$ \\
26 & $60.37 \pm 1.01$ & $83.57 \pm 3.61$ & $13.23 \pm 1.6$ & $3.2 \pm 2.01$ \\
27 & $61.2 \pm 2.51$ & $86.03 \pm 0.85$ & $9 \pm 2.96$ & $4.97 \pm 2.12$ \\
\hline & & & & \\
\hline
\end{tabular}

Table 6. Factor contributions (\%) to ANOVA models for content and digestion of millet extrudates

\begin{tabular}{lllll}
\hline Factor (\%) & TSC & RDS & SDS & RS \\
\hline T & 3.87 & $11.16^{* *}$ & 4.22 & 3.96 \\
$\mathrm{M}$ & $18.58^{* * *}$ & $24.79^{* * *}$ & $14.46^{* *}$ & $19.15^{* * *}$ \\
$\mathrm{SS}$ & 6.60 & 3.69 & $15.33^{* *}$ & 6.67 \\
$\mathrm{~T} * \mathrm{M}$ & 1.64 & 1.95 & 1.66 & 1.43 \\
$\mathrm{~T} * \mathrm{SS}$ & 1.81 & 0.69 & 0.90 & 2.02 \\
$\mathrm{M} * \mathrm{SS}$ & 3.25 & 0.86 & 3.07 & 2.97 \\
$\mathrm{~T} * \mathrm{M} * \mathrm{SS}$ & 2.43 & 0.37 & 7.10 & 8.37 \\
Error & 59.83 & 56.48 & 53.25 & 55.42 \\
\hline
\end{tabular}

Note. ${ }^{*} \mathrm{p}<0.05 ; * * \mathrm{p}<0.01 ; * * * \mathrm{p}<0.001$.

\subsubsection{Total Starch Content of Extrudates}

Total starch content is an important index for cereal-based products. Starch concentration of the extrudates ranged from $61.63 \%$ to $74.87 \%$, which was significantly affected by moisture. Lower moisture content decreased the starch concentration of the extrudates. This may be due to changes in the shear force and the susceptibility of high molecular weight branched amylopectin to shear degradation during extrusion processing, resulting in variations in the total starch content of the extrudates ( $\mathrm{Li}$ et al., 2017).

\subsubsection{In vitro Starch Digestibility of Extruded Millet Flour}

RDS, SDS, and RS of the extrudates varied from $79.5 \%$ to $90.07 \%, 8.07 \%$ to $14.1 \%$, and $1.03 \%$ to $7.0 \%$, respectively (Table 3), which was significantly affected by extrusion temperature and moisture content. During extrusion, starch gelatinization directly affected its digestibility. Furthermore, high temperatures increased the degree of starch gelatinization, which increased its digestibility (Rathod \& Annapure, 2017). In addition, the 
RDS of extrudates mainly exhibited a quadratic relationship with moisture content and reached the maximum value at moderate moisture condition (26\%). This result agrees with those of Su et al. (2017), the rate of digestion of RDS and saliva/gastric juice-digested starch of sorghum-barley blend exhibited a quadratic relationship with the moisture content with $30 \pm 4.3 \%$ as the critical moisture. Furthermore, the starch digestibility properties of extrudates were not significantly affected by the screw speed $(\mathrm{P}>0.05)$. The rate of starch digestion, indices of water binding, and solubility reduced, and the extrudates were denser when extrusion was performed in the presence of high moisture content. In this study, we have discussed the in vitro digestion patterns of intestinal enzymes, but have not investigated those of enzymes in other phases such as in the oral cavity and stomach, which is a limitation of the study.

\section{Conclusion}

In summary, this study reveals how physicochemical properties and starch digestibility of millet are affected by extrusion. High extrusion temperature increases REI and starch digestibility of the extrudates but decreased BD. High moisture content and low screw speed increased BD and total starch content while decreasing REI and WSI. When extrusion temperature and moisture content were increased, WSI and starch digestibility increased first, followed by a decrease. However, WAI is affected by the interaction among various conditions. The extrudates were darker and yellower than native millet. Thus, extrusion conditions can redefine the properties of produced millet, which can be significant for altering its market value and increasing the diversity of millet products.

\section{References}

Almeidadominguez, H. D., Gomez, M. H., Sernasaldivar, S. O., Waniska, R. D., Rooney, L. W., \& Lusas, E. W. (1993). Extrusion cooking of pearl millet for production of millet-cowpea weaning foods. Cereal Chemistry, 70, 214-219.

Alonso, R., Grant, G., Dewey, P., \& Marzo, F. (2000). Nutritional assessment in vitro and in vivo of raw and extruded peas (Pisum sativum L.). Journal of Agricultural \& Food Chemistry, 48(6), 2286-2290. https://doi.org/10.1021/jf000095o

Ames, J. M. (1998). Applications of the Maillard reaction in the food industry. Food Chemistry, 62(4), 431-439. https://doi.org/10.1016/S0308-8146(98)00078-8

Annor, G. A., Tyl, C., Marcone, M., Ragaee, S., \& Marti, A. (2017). Why do millets have slower starch and protein digestibility than other cereals? Trends in Food Science \& Technology, 66, 73-83. https://doi.org/ 10.1016/j.tifs.2017.05.012

Association of Official Analytical Chemists. (2000). Ash of flour. Method 923.03. Washington, DC: Association of Official Analytical Chemists.

Association of Official Analytical Chemists. (2000). Fat in flour. Method 922.06. Washington, DC: Association of Official Analytical Chemists.

Association of Official Analytical Chemists. (2000). Official Method AOAC 925.10 for Moisture in Flour. Gaithersburg, Maryland, DC: Association of Official Analytical Chemists.

Association of Official Analytical Chemists. (2002). Official Method. Protein, Official methods of analysis of AOAC International (16th ed.). Arlington, Virginia, DC: Association of Official Analytical Chemists.

Brahma, S., Weier, S. A., \& Rose, D. J. (2016). Effects of selected extrusion parameters on physicochemical properties and in vitro starch digestibility and $\beta$-glucan extractability of whole grain oats. Journal of Cereal Science, 70, 85-90. https://doi.org/10.1016/j.jcs.2016.05.001

Englyst, H. N., Kingman, S. M., \& Cummings J. H. (1992). Classification and measurement of nutritionally important starch fractions. European Journal of Clinical Nutrition, 46(Suppl. 2), 33-50.

George, A. A., Catrin, T., Massimo M., Zhu, Z. Z., Barba, F. J., Ralf, G., ... Roohinejad, S. (2017). Effect of extrusion on the anti-nutritional factors of food products: Anoverview. Food Control, 79, 62-73. https://doi.org/10.1016/j.foodcont.2017.03.027

Guo, Q., Joseph, M., Setia, R., Vikhona, H., Sharma, K., \& Alavi S. (2018). Extruded corn soy blends: Physicochemical and molecular characterization. Journal of Cereal Science, 79, 486-493. https://doi.org/ 10.1016/j.jcs.2017.12.012

Hagenimana, A., Ding, X., \& Fang, T. (2006). Evaluation of rice flour modified by extrusion cooking. Journal of Cereal Science, 43, 38-46. https://doi.org/10.1016/j.jcs.2005.09.003 
Jongsutjarittam, O., \& Charoenrein, S. (2014). The effect of moisture content on physicochemical properties of extruded waxy and non-waxy rice flour. Carbohydrate Polymers, 114, 1492-1501. https://oi.org/10.1016/ j.carbpol.2014.07.074

Kharat, S., Medina-Meza, I. G., Kowalski, R. J., Hosamani, A., Ramachandra, C. T., Hiregoudar, S., \& Ganjyal, G. M. (2019). Extrusion processing characteristics of whole grain flours of select major millets (foxtail, finger, and pearl). Food and Bioproducts Processing, 114, 60-71. https://doi.org/10.1016/j.fbp.2018.07.002

Kraithong, S., Lee, S., \& Rawdkuen, S. (2017). Physicochemical and functional properties of Thai organic rice flour. Journal of Cereal Science, 79, 259-266. https://doi.org/10.1016/j.jcs.2017.10.015

Li, M., Hasjim, J., \& Xie, F. W, (2014), Shear degradation of molecular, crystalline, and granular structures of starch during extrusion. Starch (Stärke), 66(7), 595-605. https://doi.org/10.1002/star.201300201

Liang, K. H., Liang, S., Lu, L. G., Zhu, D. Z., Zhu H., Liu, P., \& Zhang, M. (2018). Metabolic variation and cooking qualities of millet cultivars grown both organically and conventionally. Food Research International, 106, 825-833. https://doi.org/10.1016/j.foodres.2018.01.023

Maskan, M., \& Altan, A. (2011). Advances in food extrusion technology (pp. 132-155). CRC Press.

Minekus, M., Alminger, M., Alvito, P. A., Balance, S., Bohn, T., Bourlieu, C., ... Brodkorb, A. (2014). A standardised static in vitro digestion method suitable for food-An international consensus. Food \& Function, 5(6), 1113-1124. https://doi.org/10.1039/C3FO60702J

Natabirwa, H., Muyonga, J. H., Nakimbugwe, D., \& Lungaho, M. (2018). Physico-chemical properties and extrusion behaviour of selected common bean varieties. Journal of the Science of Food \& Agriculture, 98(4), 1492-1501. https://doi.org/10.1002/jsfa.8618

Parameswaran, K. P., \& Sadasivam, S. (1994). Changes in the carbohydrates and nitrogenous components during germination of proso millet, Panicum miliaceum. Plant Foods for Human Nutrition, 45(2), 825-833. https://doi.org/10.1007/BF01088466

Patil, S. S., Rudra, S. G., Varghese, E., \& Kaur, C. (2016). Effect of extruded finger millet (Eleusine coracan L.) on textural properties and sensory acceptability of composite bread. Food Bioscience, 14, 62-69. https://doi.org/10.1016/j.fbio.2016.04.001

Pradeep, S. R., \& Guha, M. (2011). Effect of processing methods on the nutraceutical and antioxidant properties of little millet (Panicum sumatrense) extracts. Food Chemistry, 124(4), 1643-1647. https://oi.org/10.1016/ j.foodchem.2010.12.047

Rathod, R. P., \& Annapure, U. S. (2017). Physicochemical properties, protein and starch digestibility of lentil based noodle prepared by using extrusion processing. LWT-Food Science and Technology, 80, 121-130. https://doi.org/10.1016/j.lwt.2017.02.001

Sayanjali, S., Ying, D., Sanguansri, B. L. R., Augustin, M. A., \& Gras, S. L. (2017). The effect of extrusion on the functional properties of oat fibre. LWT-Food Science and Technology, 84, 106-113. https://doi.org/ 10.1016/j.lwt.2017.05.025

Shafi, S., Wani, IA., Gani, A., Sharma, P., Wani, H. M., Masoodi, F. A., ... Hamdani, A. M. (2016). Effect of water and ether extraction on functional and antioxidant properties of Indian horse chestnut (Aesculus indica Colebr) flour. Journal of Food Measurement \& Characterization, 10(2), 387-395. https://doi.org/ 10.1007/s11694-016-9317-0

Shivendra, S., Shirani, G., \& Lara W. (2007). Nutritional aspects of food extrusion: A review. International Journal of Food Science \& Technology, 42(8), 916-919. https://doi.org/10.1111/j.1365-2621.2006.01309.x

Stojceska, V., Ainsworth, P., Plunkett, A., \& İbanoğlu, Ş. (2008). The effect of extrusion cooking using different water feed rates on the quality of ready-to-eat snacks made from food by-products. Food Chemistry, 114(1), 226-232. https://doi.org/10.1016/j.foodchem.2008.09.043

Su, S. K., Jin, X., Jing, Z., \& Sopade, P. A. (2017). Extrusion of a model sorghum-barley blend: Starch digestibility and associated properties. Journal of Cereal Science, 75, 314-323. https://doi.org/10.1016/ j.jcs.2017.04.007

Suksomboon, A., Limroongreungrat, K., Sangnark, A., Thititumjariya, K., \& Noomhorm A. (2011). Effect of extrusion conditions on the physicochemical properties of a snack made from purple rice (Hom Nil) and soybean flour blend. International Journal of Food Science \& Technology, 46(1), 201-208. https://doi.org/ 10.1111/j.1365-2621.2010.02471.x 
Teba, C. S., Silva, E. M. M., Chávez, W. H., Carvalho, C. W. P., \& Ascheri, J. L. R. (2017). Effects of whey protein concentrate, feed moisture and temperature on the physicochemical characteristics of a rice-based extruded flour. Food Chemistry, 228, 287-296. https://doi.org/10.1016/j.foodchem.2017.01.145

Tucker, G., Plunkett, A., \& Ainsworth, P. (2006). The effect of extrusion conditions on the functional and physical properties of wheat-based expanded snacks. Journal of Food Engineering, 73(2), 142-148. https://doi.org/10.1016/j.jfoodeng.2005.01.013

Wu, Y., Lin, Q. L., Cui, T., \& Xiao H., X. (2014). Structural and physical properties of starches isolated from six varieties of millet grown in China. International Journal of Food Properties, 17(10), 408-416. https://doi.org/10.1080/10942912.2013.803119

Yadav, D. N., Anand, T., Chhikara, N., \& Singh, A. K. (2014). Co-extrusion of pearl millet-whey protein concentrate for expanded snacks. International Journal of Food Science \& Technology, 49(3), 840-846. https://doi.org/10.1111/ijfs. 12373

Yu, L., \& Ramaswamy, H. S. (2012). Twin-screw Extrusion of Corn Flour and Soy Protein Isolate (SPI) Blends: A Response Surface Analysis. Food \& Bioprocess Technology, 5(2), 485-497. https://doi.org/10.1007/ s11947-009-0294-8

Zhang, B., Liu, G., Ying, D. Y., Sanguansri, L., \& Augustin, M. A. (2017). Effect of extrusion conditions on the physico-chemical properties and in vitro protein digestibility of canola meal. Food Research International, 100(Pt. 1), 658-664. https://doi.org/10.1016/j.foodres.2017.07.060

Zhao, X. W., An, G. J., Wang, Z. G., Wei, Y. M., \& Zhang, B. (2015). Protein modifications after foxtail millet extrusion: Solubility and molecular weight. Advance Journal of Food Science \& Technology, 7(7), 522-529. https://doi.org/10.19026/ajfst.7.1353

\section{Copyrights}

Copyright for this article is retained by the author(s), with first publication rights granted to the journal.

This is an open-access article distributed under the terms and conditions of the Creative Commons Attribution license (http://creativecommons.org/licenses/by/4.0/). 